\title{
2-Deoxy-25-methyldolichosterone and 3-epi-2-Deoxy-25-methyldolichosterone in Immature Seeds of Phaseolus vulgaris
}

\author{
Chan-Ho Park, Takao Yokota, ${ }^{\dagger}$ and Seong-Ki Kim \\ Department of Life Science, Chung-Ang Lniversity, Seoul 156-756, Korea. "E-mail: skkimbioracau.ackr \\ ${ }^{\dagger}$ Department of Biosciences. Teikvo University. Utsumomiva, 320-8551, Japan \\ Received June 20, 2009, Accepted August 17, 2009
}

Key Words: Brassinosteroids, Phaseolus vulgaris. Biosynthesis, Biological activity. 24-Methylene-25methỵl-BRs

Steroidal plant hormones. collectively named Brassinosteroids (BRs). control various aspects of the growth and development of plants such as stem elongation, photomorphogenesis. leaf and flower development, stress modulation and sink/source relationship. ${ }^{1-2}$ A number of naturally-occurring BRs have been identified in the plant kingdom from algae to higher plants. "The naturally-occurring BRs can be classified as $\mathrm{C}_{2}-\mathrm{C}_{2 x-\text { and }} \mathrm{C}_{2}-\mathrm{BR}$ based on numbers of the carbon skeleton. ${ }^{4}$ 25-Methyldolichosterone (1. Fig. 1) which has been identified from immature seeds of $P$. vilgaris is a unique $\mathrm{C}_{2}-\mathrm{BR}$ because it carries a tertiary butyl moiety at the end of
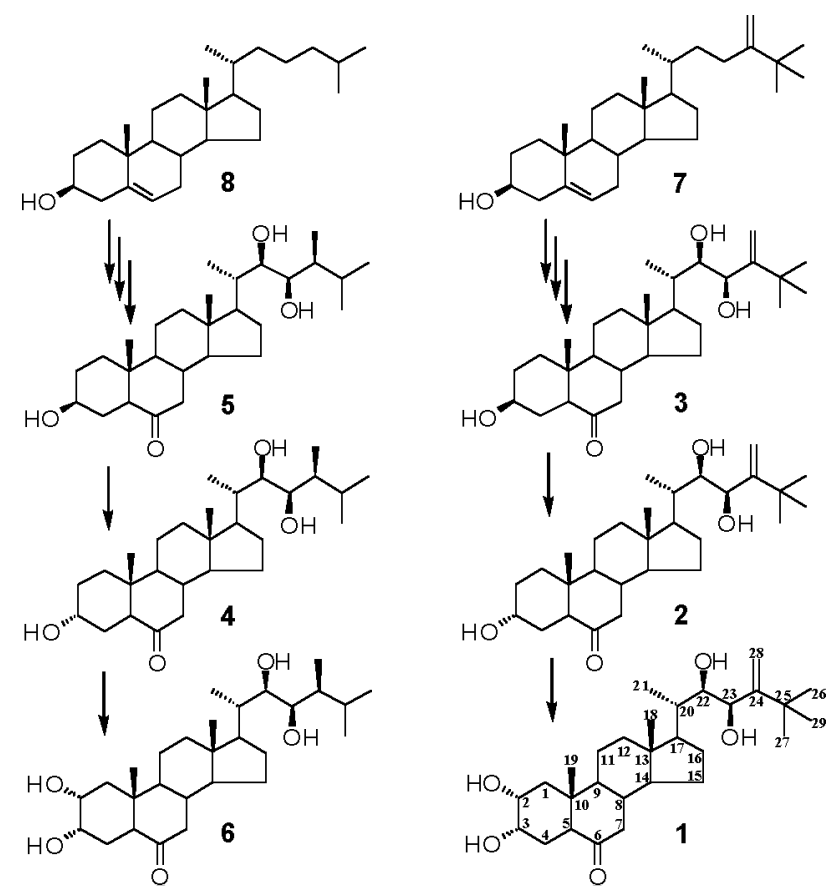

Figure 1. Biosynthetic pathway for 24-methyl-BRs and 24-methylene-25-methyl-BRs in $P$. vilgaris. The multiple arrows indicate multi-biosynthetic steps 1:25-methyldlichosterone, 2:2-deoxy-25methyldlichosterone, 3:3-epi-2-deosy-25-methyldlichosterone, 4:2deoxycastasterone, 5:3-epi-2-deoxycastasterone, 6:castasterone, 7:24methylene-25-methylcholesterol, 8:24-methylcholesterol. the side. ${ }^{5}$ A comparison of the bioactivities of dolichosterone and 1 revealed that methylation at C-25 increases BRs activity. inplying that $\mathbf{1}$ is a physiologically important $\mathrm{BR}^{6}$ Nevertheless, how 1 is biosynthesized in plants has not been established yet. This prompted us to search again for the presence of biosynthetic precursors of 1 in immature seeds of P. vulgaris. That search led to identification in seeds of two new BRs with a tertiary butyl at the end of the side chain. 2-deoxy-25-methỵldolichosterone (2) and 3-epi-2-deoxy-25methyyldolichosterone (3). Here, stnuctural elucidation. biological activity and biogenesis of the BRs are reported.

Extraction solvent partitioning and column chromatography for purification of BRs from $P$. vilgaris have been reported. ${ }^{\text {? }}$ Using a large-scale reverse-phase HPLC method (Shenshu Pak. Develosil ODS $5 \mu \mathrm{m}, 20 \times 250 \mathrm{~nm}$ ) with an elution flow rate of $20 \mathrm{~mL} \mathrm{~min}^{-1}$ with $45 \%$ acetonitrile as the mobile phase. a compound in fraction 45 showed a blue-purplish spot on HPTLC (Merck, $F_{254}$ ) with an $R_{f}$ of 0.52 after heating followed by spraying with $70 \%$ sulfuric acid. The compound (I) was further purified by a small-scale. normal phase HPLC method (Shensu Pak, Aquasil. $10 \times 200 \mathrm{~mm}$ ). It eluted at a flow rate of $3 \mathrm{~mL} \mathrm{~min}{ }^{.1}$ with a gradient of increasing iso-propanol in n-hexane $(0 \sim 20 \mathrm{~min}: 25 \%, 20 \sim 40 \mathrm{~min}$ : gradient to $60 \%$ isopropanol in $n$-hexane). The fraction eluting between 17 and 18 min showed biological activity in the rice lanina inclination. The fractions were combined and used for instrumental analyses. After the same large-scale reversed-phase HPLC, a compound (II) in fraction 50 also showed a blue-purplish spot on HPTLC with an $R_{f}$ of 0.52 after heating followed by spraying with $70 \%$ sulfuric acid. II was further purified by the aforementioned small-scale normal phase HPLC. giving rise to biologically active fractions 10 and 11 in the rice lamina inclination assay: The fractions were combined and used for instrumental analyses.

For GC-MS analysis (JEOL DX303, EI, $70 \mathrm{eV}$ ). I and II were derivatized with methaneboronic acid in pyridine followed by heating at $70^{\circ} \mathrm{C}$ for $30 \mathrm{~min}$. However. no ion peaks were found on a total ion chromatogram (TIC). Instead. methaneboronation followed by trimethylsily lation (MSTFA) 
gave a sharp peak on TIC, implying that I and II have vicinal hydroxyls and an isolated hydroxyl in the structure. In methaneboronate-trimethy'silylic (MB-TMSi) ether. both I and II showed the same molecular ion at an $m / z$ of 556 and prominent ions at $m / z$ ratios of $541.527,443,359,329.167,138$, and 123 (Table 1 ). Prominent ions at $\mathrm{m} / \mathrm{z} 167,138$ and 123 are characteristic ions due to fission of $\mathrm{C}-20 / \mathrm{C}-22$ and $\mathrm{C}-22 / \mathrm{C}-23$ for 25 -methyldolichosterone $\mathrm{MB}$, suggesting that a vicinal hydrosyl is present in the side chain at $\mathrm{C}-22$ and $\mathrm{C}-23{ }^{9}$ Therefore, the location of an isolated hydroxyl in $\mathbf{I}$ and $\mathbf{I}$ is thought to be in the ring structure, most likely at $\mathrm{C}-2$

In a $400 \mathrm{NMR}$ proton analy sis. signals for protons derived from the side chain of I at o $0.96\left(3 \mathrm{H} . \mathrm{d}_{1} \mathrm{H}_{3}-21\right) .1$. $11(9 \mathrm{H} . \mathrm{s}$, $\mathrm{H}_{3}-26.27$ and 29). 3.76 (H. d. H-22). 4.07 (H. d. H-23) 5. 09 $(\mathrm{H}, \mathrm{s} . \mathrm{H}-28)$ and $5.15(\mathrm{H} . \mathrm{s} . \mathrm{H}-28)$ were exactly the same as those for 1 (Table 2). Together with the same chemical shift at o 0.61 for methyl at $\mathrm{C}-18$. this shows that I has the identical side chain structure to that of 1. C-21 methyl. C-22R and C-23R diols. $\mathrm{C}-2+$ exomethy lene and a tertiary butyl at the end of the side chain. Absorptions for trans $\mathrm{A} / \mathrm{B}$ ring protons of I were assignable to $\delta 0.73\left(3 \mathrm{H} . \mathrm{s} . \mathrm{H}_{3}-19\right), 4.17(\mathrm{H}$, br.s, H-3) $2.73(\mathrm{H}$, t. $\mathrm{H}-5)$ and $2.3 \mathrm{l}(\mathrm{H}, \mathrm{dd} . \mathrm{H}-7)$. These chemical shifts are equal to those of 2-deoxycastasterone (4). indicating that I has the same $\mathrm{C}-3 \alpha$ hỳdroxyl and 6 -ketone in its $\mathrm{A} / \mathrm{B}$ ring structure as those of + (Table 2). Taken together, these findings suggested that $\mathbf{I}$ carried the same side chain structure as that of $\mathbf{1}$ and the same ring structure as that of $\mathbf{4}$. Therefore. I was characterized and found to be 2. (22R. 23R)-30,22, 23-trihydroxy-25-methyl$5 \alpha$-ergost-24(28)-en-6-one (Fig. 1).

II also showed the same absorptions for protons derived from the side chain and $\mathrm{C}-18$ methyl at $\delta 0.96\left(3 \mathrm{H} . \mathrm{d}, \mathrm{H}_{3}-2 \mathrm{l}\right)$. $1.11\left(9 \mathrm{H}, \mathrm{s}, \mathrm{H}_{2}=26,27,29\right) .3 .76(\mathrm{H}, \mathrm{d} . \mathrm{H}-22), 4.07(\mathrm{H}, \mathrm{d}$, H-23), 5.09 (H, s. H-28). 5.15 (H. s, H-28) and 0.61 (3H. s, $\mathrm{H}_{3}-18$ ). indicating that the side chain of $\mathbf{I}$ is also identical to that of 1. Proton signals for the $\mathrm{A} / \mathrm{B}$ ring were assignable to $\delta$ $0.75\left(3 \mathrm{H} . \mathrm{s} . \mathrm{H}_{3}-19\right), 3.58(\mathrm{H}$. br. $\mathrm{H}-3), 2.22(\mathrm{H} . \mathrm{dd} . \mathrm{H}-5)$ and $2.31(\mathrm{H}$, dd. $\mathrm{H}-7)$ which are superimposed on those of 3-epi2-deoxycastasterone (5), showing that the A/B ring structure of $\Pi$ is identical to that 5 . Therefore. II was thought to have the same side chain and ring structure as that of 1 and 5 . respectively: Thus. II was determined to be 3. $(22 R, 23 R)-3 \beta, 22$. 23-triltydrosy-25-methyl-5 $\alpha$-ergost-24(28)-en-6-one (Fig. 1).

Biological activity of $\mathbf{2}$ and $\mathbf{3}$ was tested by the rice lamina inclination assay. "As shown in Figure 2.3 showed almost no activity up to $0.002 \mathrm{ppm}$, and weak activity at $0.02 \mathrm{ppm}$. Similarly. 2 exhibited very weak activity up to $0.002 \mathrm{ppm}$. and moderate activity at $0.02 \mathrm{ppm}$. Compared to the biological activity of 1 , the activity was approximately $1 / 5$ and $1 / 15$ less

Table 1. GC-MS data for 1, I and I indentified for inmature seeds of $P$. vigoris.

\begin{tabular}{ccl}
\hline Compound & $\mathrm{Rt}^{4}$ on $\mathrm{GC}$ & \multicolumn{1}{c}{ Prominent ion" $(\mathrm{m} / \mathrm{z}$, relative intensity) } \\
\hline I & 27.25 & $524(\mathrm{M}+, 18), 411(5), 387(17), 356(4), 327(21), 167(44), 138(100,123(54)$ \\
I & 16.48 & $556(\mathrm{M}+, 59) 541(28), 527(21), 443(9), 359(23), 329(71), 167(42), 138(100), 123(45)$ \\
II & 16.75 & $556(\mathrm{M}+, 45) 541(21), 527(9), 443(11), 359(26), 329(83), 167(52), 138(100), 123(90)$ \\
\hline
\end{tabular}

${ }^{a}$ Rt: Retention time (min). ${ }^{5}$ The samples are analyzed by a capillary GC-MS as BMB and TMS derivatives.

Table 2. $400 \mathrm{MHz}$ proton $\mathrm{NMR}$ (in $\mathrm{CDCl}_{3}$ ) data for $1,4,5, \mathbf{I}$ and $\mathbf{I}$ The chemical shifts are given in ppm from tetramethylsilane.

\begin{tabular}{|c|c|c|c|c|c|}
\hline & 1 & 4 & 5 & $\mathbf{I}$ & II \\
\hline \multicolumn{6}{|l|}{ Ring protons } \\
\hline $\mathrm{H}_{5}-18$ & $0.61 \mathrm{~s}$ & $0.61 \mathrm{~s}$ & $0.61 \mathrm{~s}$ & $0.61 \mathrm{~s}$ & $0.61 \mathrm{~s}$ \\
\hline $\mathrm{H}_{3}-19$ & $0.75 \mathrm{~s}$ & $0.73 \mathrm{~s}$ & $0.75 \mathrm{~s}$ & $0.73 \mathrm{~s}$ & $0.75 \mathrm{~s}$ \\
\hline $\mathrm{H}-2$ & $3.77 \mathrm{br}$ & - & - & - & - \\
\hline $\mathrm{H}-3$ & 4.05 br.s & 4.17 br.s & 3.58 br.s & $4.17 \mathrm{brs}$ & $3.58 \mathrm{br.s}$ \\
\hline $\mathrm{H}-5$ & $\begin{array}{c}2.69 \mathrm{dd} \\
(J=4,13 \mathrm{~Hz})\end{array}$ & $\begin{array}{c}2.73 \mathrm{t} \\
(J=8,16 \mathrm{~Hz})\end{array}$ & $\begin{array}{c}2.22 \mathrm{dd} \\
(J=5,14 \mathrm{~Hz})\end{array}$ & $\begin{array}{c}2.73 \mathrm{t} \\
(J=8,16 \mathrm{~Hz})\end{array}$ & $\begin{array}{c}2.22 \mathrm{dd} \\
(J=5,1+\mathrm{Hz})\end{array}$ \\
\hline $\mathrm{H}-7$ & $\begin{array}{c}2.29 \mathrm{dd} \\
(J=5,13 \mathrm{~Hz})\end{array}$ & $\begin{array}{c}2.31 \mathrm{dd} \\
(J=5,14 \mathrm{~Hz})\end{array}$ & $\begin{array}{c}2.31 \mathrm{dd} \\
(J=5,14 \mathrm{~Hz})\end{array}$ & $\begin{array}{c}2.31 \mathrm{dd} \\
(J=5,14 \mathrm{~Hz})\end{array}$ & $\begin{array}{c}2.31 \mathrm{dd} \\
(J=5,14 \mathrm{~Hz})\end{array}$ \\
\hline \multicolumn{6}{|c|}{ Side chain protons } \\
\hline $\mathrm{H}_{2}-2 \mathrm{I}$ & $0.96 \mathrm{~d}$ & $0.85 \mathrm{~d}$ & $0.85 \mathrm{~d}$ & $0.96 \mathrm{~d}$ & $0.96 \mathrm{~d}$ \\
\hline $\mathrm{H}_{3}-26$ & - & $0.91 \mathrm{~d}$ & $0.91 \mathrm{~d}$ & - & - \\
\hline $\mathrm{H}_{2}-27$ & - & $0.95 \mathrm{~d}$ & $0.95 \mathrm{~d}$ & - & - \\
\hline $\mathrm{H}_{2}-28$ & - & $0.97 \mathrm{~d}$ & $0.97 \mathrm{~d}$ & - & - \\
\hline $\mathrm{H}_{4}-26,27,29$ & $1.11 \mathrm{~s}$ & - & - & $1.11 \mathrm{~s}$ & $1.11 \mathrm{~s}$ \\
\hline $\mathrm{H}-22$ & $\begin{array}{c}3.76 \mathrm{~d} \\
(J=8 \mathrm{~Hz})\end{array}$ & $\begin{array}{c}3.56 \mathrm{~d} \\
(J=9 \mathrm{~Hz})\end{array}$ & $\begin{array}{c}3.56 \mathrm{~d} \\
(J=9 \mathrm{~Hz})\end{array}$ & $\begin{array}{c}3.76 \mathrm{~d} \\
(J=9 \mathrm{~Hz})\end{array}$ & $\begin{array}{c}3.76 \mathrm{~d} \\
(J=9 \mathrm{~Hz})\end{array}$ \\
\hline $\mathrm{H}-23$ & $\begin{array}{c}4.05 \mathrm{~d} \\
(J=8 \mathrm{~Hz})\end{array}$ & $\begin{array}{c}3.72 \mathrm{~d} \\
(J=9 \mathrm{~Hz})\end{array}$ & $\begin{array}{c}3.72 \mathrm{~d} \\
(J=9 \mathrm{~Hz})\end{array}$ & $\begin{array}{c}4.07 \mathrm{~d} \\
(J=9 \mathrm{~Hz})\end{array}$ & $\begin{array}{c}4.07 \mathrm{~d} \\
(J=9 \mathrm{~Hz}\end{array}$ \\
\hline $\mathrm{H}_{2}-28$ & $\begin{array}{l}5.09 \mathrm{~s} \\
5.15 \mathrm{~s}\end{array}$ & 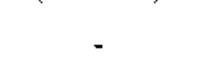 & ( & $\begin{array}{l}5.09 \mathrm{~s} \\
5.15 \mathrm{~s}\end{array}$ & $\begin{array}{l}5.09 \mathrm{~s} \\
5.16 \mathrm{~s}\end{array}$ \\
\hline
\end{tabular}




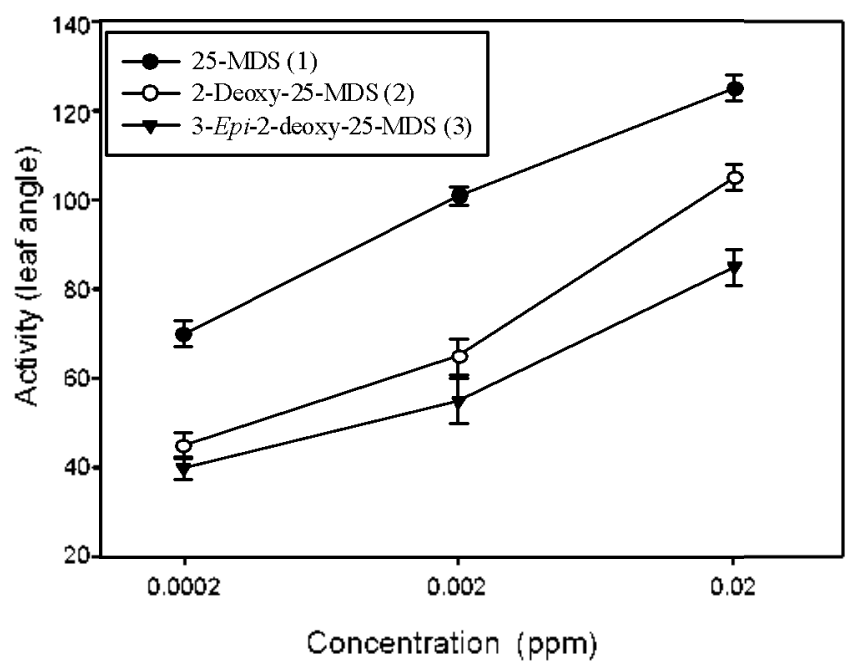

Figure 2. Biological activity for 1,2 and 3 int the rice lamina inclination assay.

active for $\mathbf{2}$ and $\mathbf{3}$, respectively.

Among the naturally-occurring BRs. castasterone (6) is the most frequently identified BR in the plant kingdom. ${ }^{3}$ Coupled with strong biological activity and a ligh endogenous level of 6. biosynthesis of BRs has been mainly focused on how 6 is biosynthesized in plants. As a result the biosynthetic pathways from campesterol to 6 . namely the early and late $\mathrm{C}-6$ oxidation pathway for $\mathrm{C}_{28}-\mathrm{BRs}$. have been established (Fig 1). It has been previously reported that $P$. vulgaris contains 6 as a major BRs. ${ }^{1}$ Additionally, the presence of biosynthetic precursors such as 6-deoxoCS. 4.5 for biosy'nthesis of 6 were demonstrated in $p$. vulgaris. ${ }^{12}$ Further. a crude enzyme solution prepared from $p$. whlgaris successfully catalyzed almost all biosy'nthetic reactions involved in the early' and late $\mathrm{C}-6$ oxidation pathway to generate 6 . showing that the biosynthetic pathways for $\mathrm{C}_{28}$-BRs are operating in these plants.

In P. vilgaris, 1 is also a major $\mathrm{BR}$ whose endogenous level is comparable to that of 6 . The presence of 24-methylene-25methyl-cholesterol (7) in the Phaseolts plant implies that biosynthetic pathways for synthesizing 1 from 7 are also functional in the plant. In this stidy. we identified two new $\mathrm{BRs}, \mathbf{2}$ and $\mathbf{3}$ from immature seeds of $P$. vilgaris. 2 and $\mathbf{3}$ are considered to be counterparts of 4 and 5 in the early $\mathrm{C}-6$ oxidation pathway for 6 . Coupled with the presence of 7 and
1. this strongly suggests that a biosynthetic pathway from 7 to 1 via 3 and 2 possibly named the early $C-6$ oxidation pathway for 24-methylene-25-methyl-BRs. is also operating in Phaseolus plants (Fig. 1). It is thus thought that a steady-state level of endogenous $\mathrm{BRs}$ is maintained by multiple biosy'nthetic pathways, at least two. in Phaseolus vulgaris.

\section{Experimental Section}

Bioasay. The rice lamina inclination assay was carried out using Cultivar Koshilikari as described Arima et $\mathrm{al}^{12}$

Instnumental Analysis. GC-MS analysis was carried out with JEOL DX303 (EI: $70 \mathrm{eV}$ ) fitted with a capillary column (DB-1. J \& W Co.. $-.254 \mathrm{~mm} \times 15 \mathrm{~m} .0 .25 \mu \mathrm{m}$ film thickness). GC condition: $1 \mathrm{~mL} \mathrm{~min}^{-1} \mathrm{He}:$ splitless injection mode: $175^{\circ} \mathrm{C}$ for 2 min. therntal gradient $32^{\circ} \mathrm{C} \min ^{-1}$ to $275^{\circ} \mathrm{C}$, and then maintained at $275^{\circ} \mathrm{C}$.

$400 \mathrm{MHz}$ proton NMR analy sis was performed by JEOL FX-400 using TMS as an internal standard.

Aclnowledgments. This work is supported by the grants from the Plant Diversity Research Center of the 2 1st Century Frontier Research Program (PF06304-03) and KOSEF/ MEST (R01-2007-000-20074-0).

\section{Refelence}

1. Bishop, G. J.: Yokota, T. Plant Cell Phusiol 2001, 42, 114.

2. Baiguz, A:; Tretyn, A. Phytochemistry 2003, 62, 1027

3. Kim, T.-W.: Hwang, J.-Y.: Kim, Y.-S.: Ioo, S.-H.; Chang, S. C.; Lee, J. S: Tákatsuto, S.: Kim, S.-K. The Plan Cell 2005, 17, 2397.

4. Fulioka, S.; Yokota. T. Amm. Rev Plant Biol. 2003, 5٪, 137

5. Baigul, A.; Tretyn, A. Phytochemistry 2003, 62, 1027.

6. Yokota, S.; Koba, S.: Kim, S.-K. Agric. Biol Chem 1987, 51, 1625 .

7. Joo, S.-H.; Hwang, J.-Y.; Park, C.-H.; Lee, S. C $;$ Kim, S.-K. Bull. Korean Chem. Soc 2009, 30, 502.

8. Park, S. C.; Kim, T.-W; Kim, S.-K. Bull. Konew Chem. Soc. $2000,21,1274$

9. Kim, T.-W: Chang, S. C.; Lee, I. S.; Takatsuto, S.; Yokota, T.; Kim S.-K. Plont Phvsiol. 2004, 135, 1231

10. Arima, M.; Yokota, T:; Takahashi, N. Phytochemistry 1984, 23, 1587.

11. Yokota, S.: Koba, S.: Kim, S.-K. Agric Biol Chem 1987, 51, 1625.

12. Fujioka S. In Brassinosteroids: Steroidal Plant Hom mones: Sakurai, A:: Yokota, T.; Clouse, S. D., Eds.: Springer-Verlag: Tokyo, $1999 ; \mathrm{p} 21$ 